\section{Improving Papaya Seedling Emergence by Matriconditioning and Gibberellin Treatment}

\author{
Claudinei Andreoli ${ }^{1}$ and Anwar A. Khan ${ }^{2}$ \\ New York State Agricultural Experiment Station, Department of Horticultural \\ Sciences, Cornell University, Geneva, NY 14456
}

Additional index words. pawpaw, growth regulator, dormancy, priming

\begin{abstract}
Papaya (Carica papaya L.) seeds germinated poorly at $25 \mathrm{C}$ in the presence of gibberellin $\left(\mathbf{G A}_{4+7}\right)$ or following matriconditioning at $25 \mathrm{C}$ for $\mathbf{4}$ days. However, a combined treatment of matriconditioning and $\mathbf{G A}_{4+7}$ for 4 days synergistically promoted germination and seedling emergence. Drying the seeds after conditioning reduced the percentage of seedling emergence in the combined treatment involving $400 \mu \mathrm{M} \mathbf{G A}_{47}$ only. Combining matriconditioning with 100 or $200 \mu \mathrm{M} \mathrm{GA_{47 }}$ could effectively reduce germination time and improve seedling emergence and is recommended as a standard procedure for testing papaya seed germination.
\end{abstract}

Papaya is cultivated in many tropical and subtropical regions. Papaya is propagated commercially by seed. The seed is enclosed in a gelatinous sarcotesta (aril or outer seedcoat), which is formed from the outer integument. Papaya seed germination frequently is slow, erratic, and incomplete (Chacko and Singh, 1966; Lange, 1961; Ramirez, 1961; Yahiro, 1979). While the sarcotesta can delay germination, dormancy also is observed in seeds from which the aril has been removed (Lange, 1961; Yahiro, 1979; Yahiro and Oryoji, 1980).

Several attempts have been made to overcome dormancy and improve papaya seed germination. Treatments such as removing sarcotesta, presoaking in water, or water leaching promote Carica spp. germination ( Chow and Lin, 1991; Riley, 1981). Gibberellin (GA $)$ treatments may (Lange, 196 1; Riley, 1981; Yahiro and Oryoji, 1980) or may not (Chacko and Singh, 1966; Ramirez, 1961) increase germination percentage, even though germination time may be reduced (Chacko and Singh, 1966; Lange, 1961; Seth, 1961; Yahiro and Oryoji, 1980). Based on previous studies, Yahiro (1979) suggested that 30 or 20/30C (16

Received for publication 16 Nov. 1992. Accepted for publication $8 \mathrm{Feb}$. 1993. This research was supported in part from a grant by Empress Brasileira de Pesquisa Agropecuária (EMBRAPA) e Conselho National de Desenvolvimento Científico e Tecnológico-Centro Nacional de Pesquisa em Milho e Sorgo, Brasilia, Brazil. We gratefully acknowledge Manville Products Corp., Denver, for MicroCel E; Imperial Chemical Industries for gibberellin $\left(\mathrm{GA}_{4+7}\right)$; and the Known-You Seed Co., Kaohsiung, Taiwan, for papaya seeds. The cost of publishing this paper was defrayed in part by the payment of page charges. Under postal regulations, this paper therefore must be hereby marked advertisement solely to indicate this fact.

'Visiting Fellow. Permanent address: Servico de Producáo de Sementes Basicas/EMBRAPA, SAIN W3 Norte (final)-Pqe Rural, Brasilia, D.F., 70.770, Brazil.

${ }^{2}$ Professor; to whom reprint requests should be addressed. $\mathrm{h} / 8 \mathrm{~h}$ ) was a suitable germination temperature. Also, if a combination of aril removal and a subsequent presoak for 30 to 42 days with 500 ppm GA failed to promote germination, then a prechill treatment should be considered (a presoak at $15 \mathrm{C}$ for 40 to 50 days promoted germination in one case). However, even with these treatments, papaya seedling emergence is slow and erratic. Watkins and Cantliffe (1983) reported that $\mathrm{GA}_{4+7}$ was more effective than $\mathrm{GA}_{3}$ in stimulating germination rate of pepper (Capsicum annuum L.) seeds.

Preplant seed conditioning or priming has been used to reduce germination time, synchronize emergence, and improve stand size of several crops (Khan, 1992). One preplant conditioning procedure, matriconditioning, uses moist solid carriers to improve seed performance. Matriconditioning has been highly effective in improving emergence and stand of many crops ( Khan et al., 1990, 1992a, 1992b; Madakadze et al., 1992).

We were interested in determining if matriconditioning alone or combined with $\mathrm{GA}_{4+7}$ would break papaya seed dormancy, shorten seedling emergence time, and improve emergence percentage.

Two lots of hybrid 'Tainung no. 1' and 'Tainung no. 2' papaya seeds supplied by Known You Seed Co., Kaohsiung, Taiwan, were used to test matriconditioning and GA treatments. Two experiments were conducted. Expt. 1 treatments consisted of seed matriconditioning with Micro-Cel E (a synthetic silicate produced by hydrothermal reaction of diatomaceous silica, hydrated lime, and water; Manville Products Corp., Denver) as a solid carrier moistened with water or $\mathrm{GA}_{4+7}$ solution at 100,200 , or $400 \mu \mathrm{M}$ in 0.47 -liter glass jars, loosely capped for 1 to 5 days. Matriconditioning occurred at $25 \mathrm{C}$ in fluorescent light $\left(16 \mu \mathrm{mol} \cdot \mathrm{m}^{-2} \cdot \mathrm{s}^{-1}\right)$. A ratio (by weight in grams) of 2 seed : 0.6 Micro-Cel E :3.75 water or $\mathrm{GA}_{4+7}$ solution was used for conditioning. After conditioning, seeds were washed in running water, wiped on paper towels, and germinated (three replications of 50 seeds each) in 9-cm petri plates on two Whatman no. 1 filter paper disks soaked in $5 \mathrm{ml}$ water or 200 $\mu \mathrm{M} \mathrm{GA}_{477}$ solution. Seeds also were soaked for $24 \mathrm{~h}$ in $200 \mu \mathrm{M} \mathrm{GA}_{4+7}$ without Micro-Cel E, wiped on paper towels, and germinated in water as above. Seedling emergence was evaluated by planting seeds in a 1 peat : 1 vermiculite mix in $30 \times 24 \times 10$-cm plastic boxes at the rate of 25 seeds per row per box (four replications). The boxes were covered with a lid to prevent evaporative cooling and moisture loss and transferred to $25 \mathrm{C}$ in continuous fluorescent light $\left(16 \mu \mathrm{mol} \cdot \mathrm{m}^{-2} \cdot \mathrm{s}^{-1}\right)$. Expt. 2 consisted of the same treatments as Expt. 1, except that, after conditioning, seeds were dried to their original weight by forced air at $25 \mathrm{C}$ for $\approx 24 \mathrm{~h}$ before being planted directly in a peat-vermiculite mix. Emergence was recorded every 2 days.

Nontreated papaya seed germination was only $6 \%$ (Table 1). Matriconditioning or $\mathrm{GA}_{4+7}$ treatment slightly promoted germination. Adding $\mathrm{GA}_{4+7}$ during matriconditioning synergistically enhanced the germination percentage. In peat-lite mix, only $10 \%$ of matriconditioned seeds emerged in 10 days compared to $5 \%$ in 14 days for nontreated seeds (Fig. 1A). However, when conditioning was combined with $400 \mu \mathrm{M} \mathrm{GA}_{4+7}$, seedling emergence reached $70 \%$ and $90 \%$ in 4 and 5 days, respectively.

Although germination rate was slightly reduced (Fig. 1B), final emergence was not adversely affected when papaya seeds conditioned in the presence of 100 or $200 \mu \mathrm{M}$ $\mathrm{GA}_{4+7}$ were dried to their original weight. In contrast, drying seemed to affect adversely the seeds treated with $400 \mu \mathrm{M} \mathrm{GA}_{4+7}$ during conditioning, as indicated by reduced final percent emergence. The time for $50 \%$ of final emergence $\left(\mathrm{T}_{50}\right)$ was 6.0, 7.0, and 7.8 days for seeds treated with 200,100 , and $400 \mu \mathrm{M}$ $\mathrm{GA}_{4+7}$, respectively. Seedling emergence in nontreated and dried matriconditioned seeds was $\leq 6 \%$, even after 20 days.

Conditioning duration in the presence of $\mathrm{GA}_{4+7}$ influenced emergence time. The $\mathrm{T}_{50}$ was reduced from 12 to 6 days as the conditioning treatment was extended from 1 to 5 days (Fig. 2). However, conditioning duration did not significantly affect emergence percentage.

Table 1. Effect of matriconditioning, with or without $\mathrm{GA}_{4+7}$, on hybrid papaya seed germination.

\begin{tabular}{|c|c|c|c|c|}
\hline \multirow[b]{4}{*}{ Treatment } & \multicolumn{4}{|c|}{ Cultivar } \\
\hline & \multicolumn{2}{|c|}{ Tainung no. 1} & \multicolumn{2}{|c|}{ Tainung no. } \\
\hline & \multicolumn{4}{|c|}{ Time after seeding (days) } \\
\hline & 6 & 12 & 6 & 12 \\
\hline \multicolumn{5}{|c|}{ Germination (\%) } \\
\hline Nontreated & $0 \mathrm{c}^{2}$ & $6 \mathrm{c}$ & $0 \mathrm{~b}$ & $0 \mathrm{c}$ \\
\hline $\mathrm{GA}_{4+7^{y}}$ & $10 \mathrm{~b}$ & $25 \mathrm{~b}$ & $0 \mathrm{~b}$ & $12 \mathrm{~b}$ \\
\hline $\mathrm{MC}^{\mathrm{x}}$ & $6 \mathrm{bc}$ & $10 \mathrm{c}$ & $0 \mathrm{~b}$ & $4 \mathrm{c}$ \\
\hline $\mathrm{MC}+\mathrm{GA}_{4+7^{\mathrm{x}}}$ & $74 \mathrm{a}$ & $88 \mathrm{a}$ & $42 \mathrm{a}$ & $52 \mathrm{a}$ \\
\hline
\end{tabular}

${ }^{7}$ Mean separation within columns by ${ }_{1 . S \mathrm{D}}$ at $P<0.05$. 'Seeds were soaked in $200 \mu \mathrm{MGA}_{4+7}$ for $24 \mathrm{~h}$, wiped on paper towels, and transferred to petri plates for germination.

${ }^{\mathrm{N}} \mathrm{MC}=$ matriconditioned. Seeds were conditioned for 4 days with or without $200 \mu \mathrm{M} \mathrm{GA}_{4+}$. 


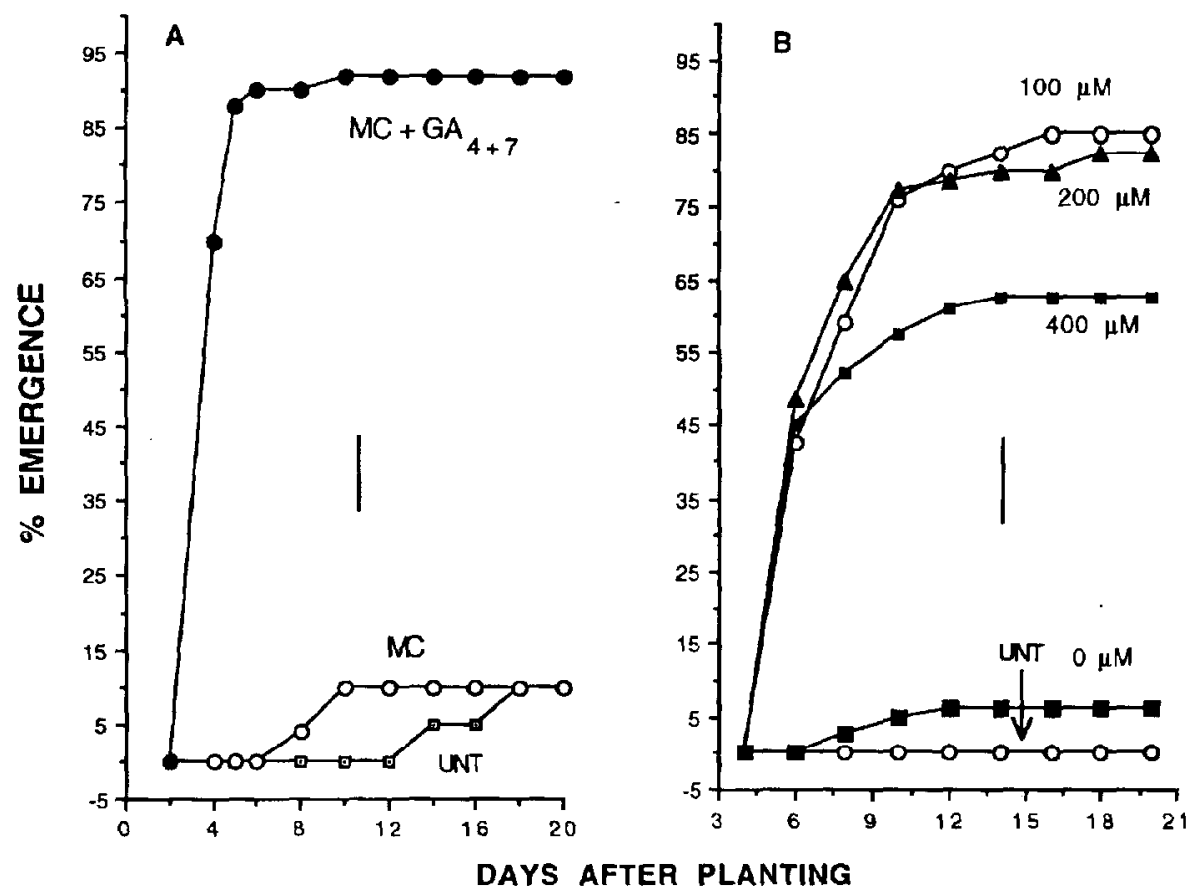

Fig. 1. (A) Enhancing emergence of 'Tainung no. L' papaya seed by combined matriconditioning and 400 $\mu_{\mathrm{M} \mathrm{GA}} \mathrm{GA}_{4+7}$ treatment for 4 days. Seeds were planted without drying to original weight. (B) The combined effect of matriconditioning and $\mathrm{GA}_{4+7}(100,200$, and $400 \mu \mathrm{M})$ for 4 days on 'Tainung no. 1' papaya seedling emergence after drying to original weight before planting. $\mathrm{MC}=$ matriconditioned seeds, $\mathrm{MC}$ $+\mathrm{GA}_{4+7}=$ matriconditioned in presence of $\mathrm{GA}_{4+7}, \mathrm{UNT}=$ nontreated seeds. Vertical bars $=\mathrm{LSD}_{0.05}$.

Germination inhibitors isolated from papaya seeds interfere with germination (Chow and Lin, 1991; Wolf and Spencer, 1984). GA action in seeds can he blocked by the presence of an inhibitor; removing the inhibitor or its effect by an antagonist permits GA action (Khan, 1971). Our results also indicate that the promotive action of $\mathrm{GA}_{4+7}$ may be blocked by inhibitory factors in the seed when the seeds are soaked directly in GA solution. It seems that the inhibitor is rendered ineffective during conditioning, thus permitting $\mathrm{GA}_{4+7}$ to influence germination or emergence.

Alternatively, inhibitors present in papaya seeds may have properties permitting them to be selectively exchanged with Micro-Cel E, which adsorbs various types of organic and inorganic chemicals. (Khan, 1992). In tomato (Lycopersicon esculentum L.) and pepper seeds, GA promotes mannanase activity, which is implicated in the digestion of the endosperm, thereby removing the mechanical constraint on embryo growth (Groot and Karssen, 1987; Watkins and Cantliffe, 1984). A similar mechanism may be operative in papaya, in the absence of inhibitors, during conditioning. Thus, matriconditioning papaya seeds in the pres- ence of $\mathrm{GA}_{4+7}$ is a highly practical means of reducing germination time and improving seedling stand.

Chacko, E.K. and R.N. Singh. 1966. The effect of gibberellic acid on the germination of papaya seeds and subsequent seedling growth. Trop. Agr. Trinidad 43:341-346.

Chow, Y.-J. and C.-H. Lin. 1991. p-Hydroxybenzoic acid as the major phenolic germination inhibitor of papaya seed. Seed Sci. Technol. 19:167-174.

Groot, S.P.C. and C.M. Karssen. 1987. Gibberellins regulate seed germination in tomato by endosperm weakening: A study with gibberellindeficient mutants. Planta 171:525-531.

Khan, A.A. 1971. Cytokinins: Permissive role in seed germination. Science 171:853-859. ditioning. Hort. Rev. 13:131-179,

Khan, A. A., G.S. Abawi, and J.D. Maguire. 1992a. Integrating matriconditioning and fungicidal treatment of table beet seed to improve stand establishment and yield. Crop Sci. 32:231-237.

Khan, A.A., J.D. Maguire, G.S. Abawi, and S. Ilyas. 1992b. Matriconditioning of vegetable seeds to improve stand establishment in early field plantings. J. Amer. Soc. Hort, Sci. 17:41-47.

Khan, A.A., H. Miura, J. Prusinski, and S. Ilyas.

\section{Literature Cited}

Khan, A.A. 1992. Preplant physiological seed con-

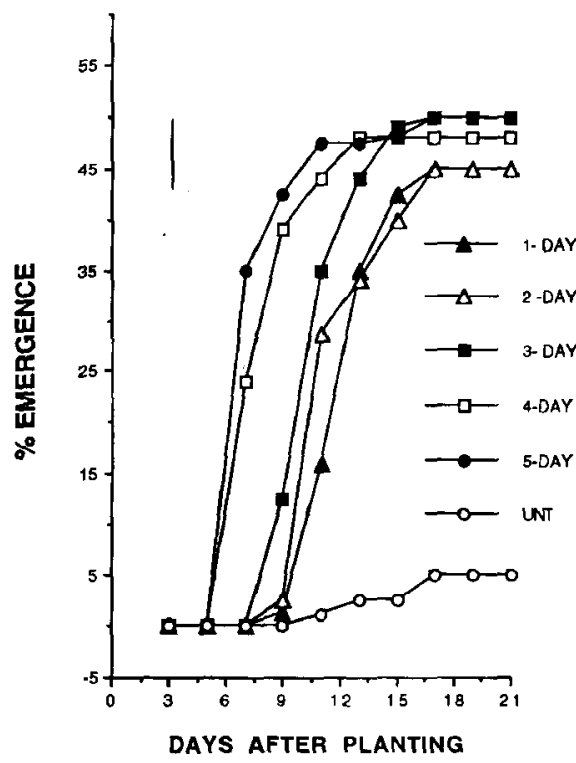

Fig. 2. The combined effect of $200 \mu \mathrm{M} \mathrm{GA} \mathrm{G}_{4+7}$ and matriconditioning ( 1 to 5 days) on 'Tainung no. 2' papaya seed emergence. Seeds were treated and planted after drying to original weight. UNT $=$ nontreated seeds. Vertical bar $=\mathrm{LSD}_{005}$.

1990. Matriconditioning of seeds to improve emergence, p. 19-40. In: Proc. Natl. Symp. Stand Establishment Hort. Crops, Minneapolis.

Lange, A.H. 1961. Effect of the sarcotesta on germination of Carica papaya. Bot. Gaz. 122:305311.

Madakadze, R., E.M. Chirco, and A.A. Khan. 1993. Seed germination of three flower species following matriconditioning under various environments. J. Amer. Soc. Hort. Sci. 118:330334.

Ramirez, O.D. 1961. Effects of gibberellic acid on germination of papaya (Carica papaya $\mathrm{L}$.) seeds. J. Agr. Univ. of Puerto Rico 45:188-190.

Riley, J.M. 1981. Growing rare fruit from seed. California Rare Fruit Growers Yrbk. 13:147.

Seth, J.N. 1961. The effect of gibberellic acid on papaya seed germination. Annu. Rpt. Hort. Res. Inst. Saharanpur p. 64-68.

Yahiro, M. 1979. Effects of seed pre-treatments on the promotion of germination in papaya, Carica papaya L. Memoirs Faculty Agr., Kagoshima Univ., Kagoshima, Japan 15:49-54.

Yahiro, M. and Y. Oryoji. 1980. Effects of gibberellin and cytokinin treatments on the promotion of germination in papaya, Carica papaya L., seeds. Memoirs Faculty of Agr., Kagoshima Univ., Kagoshima, Japan 16:45-51.

Watkins, J.T. and D.J. Cantliffe. 1983. Hormonal control of pepper seed germination. HortScience 18:342-343.

Wolf, R.B. and G.F. Spencer. 1984. Papaya vs. velvetleaf in the lab. Agr. Res. U.S. Dept. Res. Serv. 32:15-16. 